\title{
In Exile and in Touch
}

Transnational Activities of Refugees in a Comparative Perspective

Linda Bakker, Godfried Engbersen \& Jaco Dagevos

CMS 2 (3): 261-282

DOI: 10.5117/CMS2014.3.BAKK

\begin{abstract}
Studying transnational behaviour, i.e. interactions between the sending and receiving countries of international migrants, is especially interesting for refugees given their migration motive and history. Due to the flight, resources are lost and returning to the home country is often not an option; both are factors that might limit transnational behaviour. The central aim of this study is to explain the patterns of transnational behaviour for refugee groups in relation to their integration process. For this we use a large scale dataset $(\mathrm{N}=3950)$ which contains information on Somali, Iranian, Iraqi and Afghani refugees in the Netherlands. Along the lines of the 'resource dependent' thesis the analyses show that individual capacities, such as employment and Dutch nationality, are of major importance in explaining transnational activities of refugees. Second, this paper shows that the economic and social situation in the origin country should be taken into account for understanding the differences in transnational activities among refugee groups.
\end{abstract}

Keywords: Transnationalism, integration, remittances, social ties, refugee

\section{Introduction}

Interactions between the sending and receiving countries of international migrants are gauged in the concept of 'transnationalism'. Glick Schiller et al. (1992) conceptualized it as 'social processes whereby immigrants create social fields that cross geographic, cultural and political borders, and develop multiple familial, economic, social, organizational, religious, and political relations that span nations'. Studies on transnationalism among labour 
migrants show that immigrants are increasingly leading dual lives; they maintain various transnational ties and find new ways for economic mobility via cross-border networks (Levitt and Jaworsky, 2007; Portes et al. 2002). For refugees transnational behaviour might be less straightforward because of their migration motive and history. Johnson and Stoll (2008) argue for example that sending remittances to the country of origin is more stressful for refugee groups, because many of them arrive with a minimum of resources due to the spontaneous flight. Also refugees' possibilities to stay in contact with the origin country and the possibilities to return to the home country might be limited because the internet and phone network is not widely dispersed. Besides such practical reasons refugees might fear to perform any kind of transnational behaviour due to the threat of personal persecution (Mascini et al. 2012). Moreover, their perception of and identification with the home country might be distorted due to the ruling regime; therefore they might no longer want to be involved with the origin country (Díaz-Briquets and Péréz-López, 1997).

Previous research on transnationalism among refugee groups generally focussed on transnational political activities, such as the support of military actions or membership of a political organisation, advocacy or lobbying (Horst, 2008). Within the broader field of migration research, studies on transnationalism often focus on economic activities which are generally understood as sending money or goods (i.e. remittances) to the country of origin. Main topics are the determinants and mechanisms of remitting behaviour (DeSipio, 2002; Menjívar et al. 1998) and the (economic) impact of remitting on the local community of origin (see Marcelli and Lowell, 2005). Others showed the relevance of also studying socio-cultural activities, which can range from the reinforcement of national identity to involvement in everyday lives of family at home (Portes et al. 1999; Vertovec, 2001). Affordable communication and travel allows people nowadays to actively exchange between the host and home country. Therefore visiting the origin country and maintaining contact with family and friends at home are good indicators of socio-cultural transnational activities (Itzigsohn and Saucedo, 2002; Snel et al. 2006). Until recently it was argued that refugee groups arrive in the host country with limited resources and thus do not have the capacities to perform such economic or socio-cultural transnational activities. Al-Ali et al. (2001a), while studying several aspects of transnationalism by the experience of Bosnians and Eritreans refugees in Europe, were among the first to show that refugee groups are also economically and socio-culturally transnationally active (see also Snel et al. 2006). In this paper we therefore aim to further study and explain 
economic and socio-cultural transnationalism among refugee groups in terms of remittances and having contact with family and friends in the origin country and visiting the home country.

The contribution of this paper is twofold. We apply a comparative approach studying the differences in transnational behaviour between Afghani, Iraqi, Iranian and Somali refugees in the Netherlands using both a host country and origin country perspective. We use the conceptual framework of Al-Ali et al. (2001b) on individuals' capacities - or abilities - and their desire - or willingness - to participate in transnational activities. The desire is understood as the extent to which individuals and communities relate to the social, economic or political processes in their home and host country. Capacities refer to skills and resources available to the refugee but also to the internal organization of migrant communities. We combine this framework with the resource dependent and reactive transnationalism thesis of Itzigsohn and Saucedo (2002). We stress that it is important to not only study capacities and desires of refugees in the host country to be able to be transnationally active, but also include the living conditions of the stay-behinds in the origin country. Former research already showed the importance of macro level characteristics, such as political and economic stability in the home country, in explaining transnationalism (Carling et al. 2012; Hagen-Zanker and Siegel, 2007; Lindley, 2008). However, a combined theoretical model including the individual situation in the host country and the context of the origin country is innovative. Based on this we thus expect differences between the four refugee groups under study with regard to their transnational behaviour. Our research question therefore reads: how can transnational activities of the four largest refugee groups in the Netherlands be explained by individual capacities and desires in the host country? And how do these patterns differ between the four origin countries?

For this study we use large survey data $(\mathrm{N}=3950)$ gathered by the Netherlands Institute for Social Research (SCP) (Dourleijn and Dagevos, 2011), which contains extensive information on both transnational activities and diverse integration measures of the four largest refugee groups in the Netherlands; Afghan, Iraqi, Iranian and Somali. This allows us to conduct one of the first quantitative studies on transnational activities among refugees. We will bring in additional macro data that gives insight into the social and economic situation of the four origin countries. 


\section{Transnationalism: A theoretical framework in comparative perspective}

Transnationalism is often studied in relation to integration in the destination country because these are assumed to be related mechanisms (Erdal and Oeppen, 2013; Snel et al. 2006). In the traditional view (Alba and Nee, 1997) transnational activities diminishes as the process of integration advances; this is also referred to as 'linear' transnationalism. For example, a longer stay in the destination country enhances integration and simultaneously diminishes involvement in the origin country. Also it is often argued that involvement with the country of origin hinders engagement in the host society. This popular belief is not supported by academic research; ties with the country of origin can be combined with involvement in the host country (Carling, 2008; Marcelli and Lowell, 2005; Portes et al. 2002; Snel et al. 2006; Wong, 2007).

In response to this, two other mechanisms of transnationalism have been formulated. According to the 'resource dependent' transnationalism thesis economic integration goes hand in hand with participation in transnational activities (Itzigsohn and Saucedo, 2002). Capacities - skills and resources available to the refugee - in the host country, such as employment and legal status, enable migrants to send home remittances and visit the origin country. Mazzucato (2008) showed for Ghanaian migrants in the Netherlands that those who invest in the home country are at the same time engaged in making a living in the Netherlands. In the case of 'reactive transnationalism', transnational activities emerge from a lack of satisfaction with the life in the host country (Itzigsohn and Saucedo, 2002). Due to negative experiences in the host country, such as feelings of discrimination, immigrants retain a close band with the origin country (Glick Schiller and Fouron, 1998; Portes, 1999).

In this study we add another aspect to the mechanisms of resource dependent and reactive transnationalism: the situation in the origin country. Both mechanisms as formulated by Itzigsohn and Saucedo (2002) only involve the situation of migrants in the host country. We argue that, especially for refugees, the situation in the home country can also influence their transnational behaviour. Besides the resources that are available to refugees in the host country, we argue that also the resources available to the stay-behinds in the origin country can affect for example the demand for remittances (Lindley, 2008). At the same time we argue that not only the societal climate in the host country can affect the desire for transnational behaviour but also the (conflict) situation in the origin country. We 
do not have direct data on these factors on the individual level. Instead we include macro data to sketch the different economic and social contexts of the origin countries.

Refugees are often studied as one group based on their shared 'refugee experience'. However, different refugee groups clearly fled from different situations in the origin country and have a different migration history. Iranian refugees are mostly higher educated and from the urban middle class wherefore they could afford to flee the country. They were generally most threatened by the regime of ayatollah Khomeini because of their modern lifestyle and fled in order to maintain their western values and way of life (Dourleijn and Dagevos, 2011; Ghorashi, 2005; Hessels, 2002). In contrast, Somali refugees are generally low educated men who leave behind their family and community in conflict and poverty (Dourleijn and Dagevos, 2011; Hessels, 2000; Nieuwhof and Mahamoud, 2000). The Afghani mostly fled due to the strict Taliban regime and the Iraqi to escape from the 'war on terrorism' (Hessels and Wassie, 2003).

Moreover, the situation of the refugee groups in the host country varies as well. The refugee population under study together constitutes $8 \%$ of the non-western population in Dutch society. ${ }^{1}$ Of the four refugee groups under study the Iranian are the best economically integrated group in the Netherlands. Half of them are employed for more than $12 \mathrm{~h}$ a week and almost $40 \%$ has achieved some form of higher education. Paradoxically, compared to the other refugee groups, they feel the least accepted in the Netherlands. In contrast, less than a third of the Somali group has a job and more than half of the Somalis are dependent on social benefits. Also their educational level is extremely low compared to the other refugee groups. They do however feel most accepted in the Netherlands. In terms of integration in the Netherlands the Iraqi group holds a middle position together with the Afghani. About a third is employed for more than $12 \mathrm{~h}$ a week and half of them feel accepted in the Netherlands (Table 1).

Based on these two dimensions, the individual situation in the host country and situation in the origin country, we expect differences in transnational behaviour among the four refugee groups. We will use these two dimensions to derive hypotheses for the four refugee groups along the lines of resource dependent and reactive transnationalism. 
Table 1: Description of research population

\begin{tabular}{|c|c|c|c|c|}
\hline & Afghani & Iraqi & Iranian & Somali \\
\hline Number in the Netherlands* & 38,000 & 52,000 & 31,000 & 27,000 \\
\hline Socio-demographic background & Mixed & Mixed & $\begin{array}{l}\text { Mostly from } \\
\text { urban middle } \\
\text { class }\end{array}$ & $\begin{array}{l}\text { Young, single men; } \\
\text { widows; minors with- } \\
\text { out their parents }\end{array}$ \\
\hline \multicolumn{5}{|c|}{ Mode of integration (in \%) Source: SING09 } \\
\hline Employment & 35 & 34 & 49 & 30 \\
\hline Education (=high) & 23 & 26 & 35 & 6 \\
\hline Dutch nationality & 77 & 70 & 80 & 59 \\
\hline Perceived acceptance (=high) & 51 & 54 & 40 & 58 \\
\hline Exp discrimination & 6 & 6 & 8 & 6 \\
\hline
\end{tabular}

*In January 2010

\section{Hypotheses: Situation host country}

Employment and a secure legal status are considered to be important factors that influence refugees' capacity to be involved in transnational activities. Employment provides a salary and the possibility of savings. This enables refugees to both support family in the home country and to finance visits. Refugees with a refugee status often hold temporary and lower skilled jobs. Hence, in order to make a stable living in the host country, a secure legal status is necessary (Al-Ali et al. 2001b). Also a secure legal status enables refugees to travel to the country of origin. In our case, holding Dutch nationality means that they are entitled to the protection of the Dutch embassy and government in case of trouble (Muller, 2010). We argue that education and health are also important factors that can influence refugees' capacities to perform transnational activities. A higher educational level provides refugees better access to the labour market. Similarly, a good health state benefits refugees' success on the labour market. Following the mechanism of 'resource dependent' transnationalism, which states that (economic) integration goes hand in hand with participation in transnational activities, we propose the general hypothesis that refugees with more individual capacities are more likely to perform both economic and socio-cultural transnational activities (H1: resource dependent transnationalism hypothesis). Applying this mechanism to the four refugee groups under study we would expect that the Iranian group has the most capacities to perform transnational behavior, since they are best economically 
integrated. Similarly, we would expect that the Somali are the least transnational active, due to a lack of financial resources (Table 1).

Following the mechanism of 'reactive transnationalism' (Itzigsohn and Saucedo, 2002) it can be argued that negative experiences in the host country, such as discrimination, will enhance the willingness - or desire to engage in transnational activities. We thus expect that refugees who personally experience discrimination in the host country are more likely to perform socio-cultural transnational activities (H2a: reactive transnationalism hypothesis). Additionally, positive experiences in the host country may also affect the desire to be engaged in transnational activities. Carling and Hoelscher (2013) argue that a feeling of acceptance in the Netherlands and a sense of belonging might diminish the desire to remain transnationally active. Thus, we expect that refugees who perceive to be accepted in the host country are less likely to perform socio-cultural transnational activities (H2b). Since the Somali group feels most accepted in the Netherlands, we expect them to perform the least socio-cultural transnational activities. Iranians experience the most discrimination and along this line of reasoning we would thus expect them to perform most socio-cultural transnational activities. Discrimination and perceived acceptance are not two opposites on the same continuum. The first is an active and personal experience, whereas the latter represents the refugees' general view on the Netherlands as a tolerant and open country. Both hypotheses thus tap in to another mechanism to explain transnational behaviour and are therefore both included.

\section{Hypotheses: Situation origin countries}

The first obvious home related factor is the family the refugee has left behind. Clark and Drinkwater (2008) showed that remittances are more likely when parents still live in the home country. Having more distant relatives in the home country, like uncles and aunts, has no effect on the likelihood to remit. Also maintaining contact with the country of origin seems more likely when close relatives have been left behind. We thus argue that refugees who left close relatives behind (i.e. partner and children) are more likely to perform both economic and socio-cultural transnational activities (H3: close relatives hypothesis).

Besides the individual home country factors the economic and social macro level features of the countries under study (i.e. available resources in the home country) are important to consider in explaining transnational 
behaviour. Hagen-Zanker and Siegel (2007) showed that the economic and political situation of the home country influences refugees' remittances behaviour. Negative economic changes in the home country can enhance the need for remittances whereas high inflation may discourage remittances sending. Also Sana and Massey (2005) showed that variation in the situation in the country of origin shapes remittances behaviour. Johnson and Stoll (2008) propose that a situation of conflict in the origin country may increase the demand for remittances. Refugees' from these countries might also be more inclined to remit due to feelings of social obligation. Carling et al. (2012) recently showed the importance of conflict in the origin country for understanding transnationalism. On-going conflict in the country of origin indeed exerts an upward pressure on remittances sending. This leads to the general expectation that refugees from origin countries with a poor economic situation or conflict situation are more likely to remit.

Looking specifically at the four countries under study we observe that the GDP per capita in Iran is with $\$ 10,600$ by far the highest compared to $\$ 3,800$ in Iraq, $\$ 900$ in Afghanistan and only $\$ 600$ in Somalia. Regarding the life expectancy at birth Iran and Iraq hold the best position with an average around 70 years, whereas this is 50 years in Somalia and only 45 years in Afghanistan. Also with regard to education we observe that around $75 \%$ of the population aged 15 years and older in Iran and Iraq can read and write, while $38 \%$ of the Somali and only $28 \%$ of the Afghan population aged 15 years and older is literate. Together these factors shape the Human Development Index (HDI) included in the United Nations Human Development report. The index of 2013 shows that Iran is in a state of high human development (.74), the situation in Iraq is ranked as medium (.59) and the situation of human development in Afghanistan $(.37)$ and Somalia (.28) is (very) low (Table 2). Based on these indicators Iran seems to fare better than the other countries under study. On a distance Iraq follows and Somalia and Afghanistan hold the least favourable positions. More specifically, the low GDP per capita and the considerably low welfare level (i.e. literacy, life expectancy) in both Somalia and Afghanistan indicate a need for financial support in these countries. In addition, Somalia being a country in conflict ${ }^{2}$, refugees from this origin country might feel more obliged to support family in the home country. We therefore hypothesize that the likelihood of remittances sending (economic transnational activity) is highest to Somalia, followed by Afghanistan, Iraq and is the lowest to Iran ( $\mathrm{H}_{4}$ : financial stress hypothesis).

Second, communication facilities and infrastructure in the origin coun- 
try are crucial for having contact with family at home and for visiting the origin country. In general we would thus expect that refugees from origin countries with more communication facilities are more likely to perform socio-cultural transnational activities. According to the CIA world factbook Iran has the most telephone and internet users, followed by Iraq and Afghanistan. Interestingly, Afghanistan has very little telephone lines in use, but four in ten residents do have a mobile phone. Communication possibilities are the worst in Somalia. Only seven out of hundred inhabitants have direct access to a telephone (line or cellular) and only one out of hundred is an internet user (Figure 1). Additionally, since Somali is a country in conflict, contact and visits might be dangerous or impossible. We thus hypothesize that socio-cultural transnational activities are least likely to Somalia, followed by Afghanistan and Iraq and most likely to Iran $\left(_{5}\right.$ : facilities hypothesis).

Table 2: Economic and social context of origin countries: indicators for urgency financial support

\begin{tabular}{lllll}
\hline & Afghanistan & Iraq & Iran & Somalia \\
\hline GDP per capita (US dollars) & 900 & 3800 & 10600 & 600 \\
Life expectancy at birth (years) & 45 & 71 & 70 & 50 \\
Literacy (\%) & 28 & 74 & 77 & 38 \\
HDI & .37 & .59 & .74 & .28 \\
\hline
\end{tabular}

Source: CIA world factbook 2010 and United Nations Report 2012

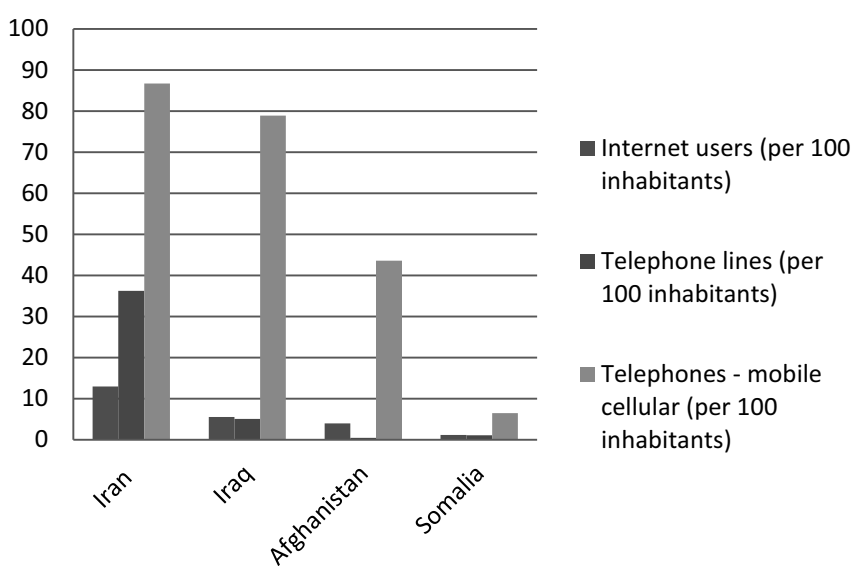

Figure 1: Origin countries technological infrastructure: indicator for communication possibilities

(Source: CIA world factbook 2010) 
It should be noted that the formulated hypotheses based on the host and home country situation are complementary for explaining socio-cultural transnational behavior. However, for explaining the economic transnational behavior of refugees seemingly contradictory hypotheses ( $\mathrm{H}_{1}$ and $\mathrm{H}_{4}$ ) are formulated. On the one hand, based on the host country situation we would expect Iranians to be the most frequent remitter, since this group is most resourceful. On the other hand, considering the home country situation, we expect the Somali group to perform most economic transnational activities due to the great urgency for financial support. All derived hypotheses are summarized in Table 3.

Table 3: Overview of hypotheses on the performance of transnational activities of refugees in the Netherlands based on the host and home country situation.

\begin{tabular}{|c|c|c|c|c|c|}
\hline General hypothesis & & Specific & ompar & e hypoth & \\
\hline $\begin{array}{l}\text { Host country situation } \\
\text { Resources/capacities } \\
\text { H1: (+) } \\
\text { Reactive } \\
\text { H2a: (disc: +) } \\
\text { H2b: (acceptance: -) }\end{array}$ & $\begin{array}{l}\text { Dependent variable } \\
\text { Economic and socio-cultural } \\
\text { transnational activities } \\
\text { Socio-cultural transnational } \\
\text { activities }\end{array}$ & $\begin{array}{l}\text { Iranian } \\
+\end{array}$ & $\begin{array}{l}\text { Iraqi } \\
+/- \\
+/-\end{array}$ & $\begin{array}{l}\text { Afghani } \\
+/- \\
+/-\end{array}$ & $\begin{array}{l}\text { Somal } \\
\text { - }\end{array}$ \\
\hline Home country situation & Dependent variable & Iranian & Iraqi & Afghani & Somali \\
\hline $\begin{array}{l}\text { Partner/children in OC } \\
\text { H3: (+) } \\
\text { Economic resources/capacities } \\
\text { H4: (-) } \\
\text { Facilities / infrastructure } \\
\text { H5: (+) }\end{array}$ & $\begin{array}{l}\text { Economic and socio-cultural } \\
\text { transnational activities } \\
\text { Economic transnational } \\
\text { activities } \\
\text { Socio-cultural transnational } \\
\text { activities }\end{array}$ & + & $\begin{array}{l}+/- \\
+/-\end{array}$ & $\begin{array}{l}+/- \\
+/-\end{array}$ & + \\
\hline
\end{tabular}

\section{$5 \quad$ Data and analyses}

\subsection{Data}

In this study we will use the Survey Integration New Groups (SING20o9) dataset gathered in 2009 by the Netherlands Institute for Social Research (SCP). This cross-sectional dataset contains information on different dimensions of transnationalism and integration of the four largest refugee groups in the Netherlands: Iraqi, Somali, Iranian and Afghan individuals. A national two step random sample was drawn, in collaboration with Statistics Netherlands (CBS), from the Municipality Records (GBA). In the first step municipalities were randomly selected. A distinction was made between medium and small municipalities. The four large cities in the Netherlands, Amsterdam, Rotterdam, Utrecht and The Hague were included by 
choice. From the selected municipalities respondents were randomly drawn. Within each refugee group about 1000 structured face-to-face interviews were conducted. In order to reach also those who had not yet mastered the Dutch language, bilingual interviewers were used for interviews with refugees who had resided in the Netherlands for a period shorter than five years.

Almost half of the sampled Afghan (49\%) and Iraqi (48\%) group participated; the response rate in the other groups was somewhat lower. Of the sampled Iranian group $44 \%$ participated and $38 \%$ of the Somali group did. ${ }^{3}$ The distribution of age and gender in the sample differs only slightly from the population. For example, Somali men are underrepresented and youngsters (in the age of 15-34) in the Afghani, Iraqi and Iranian group are underrepresented; therefore a weight was included (Dourleijn, 2010). Based on this procedure we can state that selectivity of the sample is limited and that sample is thus representative of the first generation refugee population from Iraq, Iran, Afghanistan and Somalia in the Netherlands. In this study the determination of ethnicity is based on the country of birth.

The sample population consists of members of the Afghani, Iraqi, Iranian and Somali group with a granted status and aged 15 and above $\left(\mathrm{N}=395^{\circ}\right)$. Since we are only interested in refugees with a flight experience and motive we excluded the second generation refugees $(n=91)$, as well as refugees who came for work and study purposes $(\mathrm{n}=86)$. We did include family migrants $(\mathrm{n}=662)$ since they often fled along with their partner or parent. The survey asks for the main reason of migration. Consequently, one might not personally experience fear of personal persecution but decide to flee together or after a family member who did experience a fear of personal persecution. In such cases the main migration reason might be family reunification. We argue that this group thus also has a flight experience and that they are relevant with regard of the research question about transnational activities.

\subsection{Method}

We will test separate models for 1) economic and 2) socio-cultural transnational activities. Since economic transnational activities are measured with a dichotomous variable we will conduct binary logistic regression. Sociocultural transnational activities are measured on an ordinal scale and thus an ordered logistic regression analysis is required. 


\subsection{Measures: Transnational activities}

Economic transnational activities are generally understood as remittances: sending money or goods to the home country. In this study we will use the occurrence of remittances as the measure for economic transnational activities using the direct question: 'Did you send money or goods to your origin country in the past year?' (1=yes). We are not able to measure the intensity of the activity since we do not have information on the amount of remittances sent. Socio-cultural transnational activities are measured by having contact with family in the origin country ( $1=$ never, $2=$ occasionally, $3=$ frequent $)^{4}$ and visits to the origin country (1=never, $2=$ occasionally, $3=$ each year), both on an ordinal scale. ${ }^{5}$

\subsection{Measures: Capacities and desires}

We have distinguished four possible indicators of capacities for performing transnational behavior. Employment status represents those refugees who are currently employed for more than $12 \mathrm{~h}$ a week (1) versus unemployed people and those who are looking for employment (o). Education is measured in eight categories ranging from no education to university degree. We constructed a dummy for Dutch nationality in order to measure the effect of legal status. General health is based on self-evaluation and measured on a scale from 1 (very bad) to 5 (very good).

Then, several factors which can affect the desire for refugees to engage in transnational activities are distinguished. Regarding the host country respondents were asked how often they personally experienced discrimination on a five-point scale ranging from $1=$ never to $5=$ =very often. In order to measure perceived acceptance a mean scale out of four items is used (Cronbach's $\alpha=$.77). Respondents were asked to what extent they felt that 'In the Netherlands migrants get all the chances', 'As migrant in the Netherlands all your rights are respected', 'The Netherlands is a hospitable country for migrants' and 'The Netherlands is open to other (migrant) cultures' (categories $1=$ fully disagree, $2=$ disagree, $3=$ neutral, $4=$ agree, $5=$ fully agree).

For the desires connected to the home country that can affect transnational behaviour we measure having a partner and/or children in home country with one dummy variable. Then, we control for gender (female = 1 ), age, main reason of migration ( $0=$ war, $1=$ fear of personal persecution, $2=$ family reunification, $3=$ other) and wish to return (1=yes). It should be noted that most refugees do realize that it often is not possible or realistic to return. Last, we use the natural log of the variable length of stay in years in order to prevent ourselves from extreme scores. In order to gain insight in possible differences among the refugee groups dummies per origin 
country are included (Iran $=$ ref). Summary statistics are presented in Table 4 .

Table 4: Description of dependent, independent and control variables

\begin{tabular}{|c|c|c|c|c|c|}
\hline & $\mathrm{N}$ & Min. & Max. & Mean & Std. dev. \\
\hline \multicolumn{6}{|l|}{ Dependent variables } \\
\hline Remittances & 3764 & 0 & 1 & .21 & \\
\hline Contact with family & 3561 & 1 & 3 & 2.07 & .71 \\
\hline Visit country of origin & 2822 & 1 & 3 & 1.37 & .55 \\
\hline \multicolumn{6}{|l|}{ Independent variables } \\
\hline Employment status & 3769 & 0 & 1 & .37 & \\
\hline Education & 3637 & 0 & 7 & 3.30 & 2.33 \\
\hline Dutch nationality (yes=1) & 3769 & 0 & 1 & .71 & \\
\hline Health & 3764 & 1 & 5 & 3.73 & 1.08 \\
\hline Experienced discrimination & 3655 & 1 & 5 & 1.86 & 1.04 \\
\hline Perceived acceptance & 3736 & 1 & 5 & 3.74 & .72 \\
\hline Partner/child in home country & 3769 & 0 & 1 & .04 & \\
\hline \multicolumn{6}{|l|}{ Origin country (Iran= ref) } \\
\hline Afghanistan & 3769 & 0 & 1 & .26 & \\
\hline Iraq & 3769 & 0 & 1 & .25 & \\
\hline Somalia & 3769 & 0 & 1 & .25 & \\
\hline \multicolumn{6}{|l|}{ Control variables } \\
\hline Female & 3769 & 0 & 1 & .47 & \\
\hline Age (in years) & 3769 & 15 & 90 & 36.20 & 13.06 \\
\hline Length of stay (in years) & 3769 & 1 & 42 & 12.31 & 4.80 \\
\hline Return wish (yes=1) & 3493 & 0 & 1 & .27 & \\
\hline \multicolumn{6}{|l|}{ Reason of migration (other $=$ ref) } \\
\hline War & 3769 & 0 & 1 & .41 & \\
\hline Fear of personal persecution & 3769 & 0 & 1 & .37 & \\
\hline Family reunification & 3769 & 0 & 1 & .17 & \\
\hline
\end{tabular}

\section{$6 \quad$ Results}

\subsection{Descriptive results}

About a fifth of the research population has sent home money or goods in the past year (Table 5). In general the data show that most refugees send remittances to their parents in the country of origin and to other family members. A quarter of remittances sent by Afghani refugees go to organisations in Afghanistan. About a third of the research population has frequent contact with family at home and another $50 \%$ occasionally. Al- 
most a quarter of the research population visits the country of origin occasionally. For another quarter a visit to the origin country is not possible. The Somali have the largest report of refugees who state that visiting the country of origin is not possible (Table 5). This might be an indication of conflict in the origin country which can hinder the performance of transnational activities. Further we observe that the Somali group has the largest share of remitters (29\%) and the Iranian group the smallest $(13 \%)$. The pattern of performing socio-cultural transnational activities strongly differs from that of the economic activities. Here the Iranian group has the highest percentage of maintaining contact with family at home and visiting the country of origin. The Somali followed by the Afghan group have the smallest share of refugees who perform socio-cultural transnational activities.

Table 5: Transnational activities per refugee group (in \%)

\begin{tabular}{lllllll}
\hline & Total & Afghani & Iraqi & Iranian & Somali \\
\hline Send remittances & 21 & 24 & 17 & 13 & 29 \\
Contact: Never & 22 & 27 & 15 & 9 & 36 \\
Occasionally & 49 & 53 & 54 & 50 & 40 \\
Frequent & 29 & 20 & 32 & 41 & 24 \\
Visit: Never & 52 & 55 & 46 & 40 & 65 \\
Occasionally & 23 & 22 & 29 & 35 & 6 \\
Once a year & 3 & 1 & 3 & 9 & .5 \\
Not possible & 22 & 21 & 22 & 16 & 28 \\
\hline
\end{tabular}

The bivariate relations are shown in Table 6 and are in the expected directions. Identified resources, such as employment, education and having the Dutch nationality, are positively correlated with both economic and sociocultural transnational activities. Also we observe that perceived acceptance in the Dutch society is negatively related to transnational activities. We will test whether these relations remain in a multivariate design, controlling for relevant background characteristics. Also we will further test the observed differences between refugee groups. 
Table 6: Correlation matrix (Spearman correlation)

\begin{tabular}{|c|c|c|c|c|c|c|c|c|c|c|}
\hline & Remit & $\begin{array}{l}\text { Con- } \\
\text { tact }\end{array}$ & Visit & $\begin{array}{l}\text { Em- } \\
\text { ployed }\end{array}$ & $\begin{array}{l}\text { Edu- } \\
\text { cation }\end{array}$ & $\begin{array}{l}\text { Dutch } \\
\text { nat }\end{array}$ & Health & $\begin{array}{l}\text { Perc } \\
\text { acc }\end{array}$ & $\begin{array}{l}\text { Exp } \\
\text { disc } \\
\end{array}$ & $\begin{array}{l}P / C \text { in } \\
O C\end{array}$ \\
\hline Remit & 1.00 & & & & & & & & & \\
\hline Contact & .19 & 1.00 & & & & & & & & \\
\hline Visit & .06 & .41 & 1.00 & & & & & & & \\
\hline Employed & .12 & .09 & .11 & 1.00 & & & & & & \\
\hline Education & .06 & .20 & .17 & .25 & 1.00 & & & & & \\
\hline Dutch nat & .09 & .11 & .17 & .21 & .22 & 1.00 & & & & \\
\hline Health & .11 & -.00 & .01 & .20 & .02 & .01 & 1.00 & & & \\
\hline Perc acc & -.07 & -.09 & -.11 & -.05 & -.12 & -.08 & .10 & 1.00 & & \\
\hline Exp disc & .07 & .04 & .03 & .09 & .14 & .10 & .00 & -.31 & 1.00 & \\
\hline$P / C$ in $O C$ & .02 & .05 & .01 & -.05 & -.02 & -.04 & -.07 & .01 & .00 & 1.00 \\
\hline
\end{tabular}

\subsection{Multivariate results}

The results of the binary logistic regression on the likelihood to send remittances (model 1) and the results of the ordered logistic regression on the odds of having contact with family in the country of origin (model 2) and on the odds of visiting the origin country (model 3) are presented in Table 7 . We expected that the capacities of refugees would be positively related to both economic and socio-cultural transnational activities (H1: resource dependent hypothesis). Indeed the analyses show that having a job, a higher education and better general health increases the probability of sending home money or goods, to maintain contact with family in the home country and to visit the origin country. This supports the 'resource dependent transnationalism' thesis: socio-economic integration in the host country benefits transnationalism. For having the Dutch nationality we find that this increases the odds on performing socio-cultural transnational activities. Especially for explaining visiting behaviour to the origin country having the Dutch nationality is one of the most important predictors.

Second, we do not find support for the 'reactive transnationalism' thesis. Experienced discrimination has no effect on the odds of maintaining in contact with family at home. Hypothesis $2 \mathrm{a}$ is thus rejected. We do find support for the hypothesis that perceived acceptance is negatively related to the performance of socio-cultural transnational activities $(\mathrm{H} 2 \mathrm{~b})$. Thus positive experiences in the host country (i.e. feelings of perceived acceptance) do decrease the odds on maintaining contact with family in the home country and visiting the origin country.

Third, we expected that having close relatives in the origin country would 
increase the performance of both economic and socio-cultural transnational activities. We found convincing support for this hypothesis. Indeed, having a partner or child in the home country positively affects both remittances sending and maintaining contact with family at home $\left(\mathrm{H}_{3}\right)$.

Table 7: Logistic regression on the likelihood of having sent remittances in the past year (model 1) and ordered logistic regression on the likelihood of having contact with family in country of origin (model 2) and on the likelihood of visiting the country of origin (model 3); (odds ratios, standard errors between brackets)

\begin{tabular}{|c|c|c|c|}
\hline & $\begin{array}{l}\text { Model } 1(n=3375) \\
\text { Remittances }\end{array}$ & $\begin{array}{l}\text { Model } 2(n=3099) \\
\text { Contact }\end{array}$ & $\begin{array}{l}\text { Model } 3(n=2470) \\
\text { Visit }\end{array}$ \\
\hline \multicolumn{4}{|l|}{ Origin country (Iran=ref) } \\
\hline Afghanistan & $2.98 *(.45)$ & $.35^{* *}(.04)$ & $.38^{* *}(.05)$ \\
\hline Iraq & $1.98^{* *}(.30)$ & $.73^{* *}(.07)$ & $.68^{* *}(.08)$ \\
\hline Somalia & $3.66^{* *}(.61)$ & $.34^{* *}(.04)$ & $.09^{* *}(.02)$ \\
\hline Employment & $1.57^{* *}(.16)$ & $1.24^{* *}(.10)$ & $1.27^{*}(.13)$ \\
\hline Education & $1.13^{* *}(.03)$ & $1.08^{* *}(.02)$ & 1.03 \\
\hline Dutch nationality & 1.15 & $1.60^{* *}(.15)$ & $2.37^{* *}(.35)$ \\
\hline Health & $1.17^{* *}(.06)$ & $1.11^{* *}(.04)$ & $1.11^{*}(.06)$ \\
\hline Experienced discrimination & - & 1.02 & $.90^{*}(.04)$ \\
\hline Perceived acceptance & - & $.87^{* *}(.05)$ & $.80^{* *}(.06)$ \\
\hline Partner/child in home country & $2.03^{* *}(.47)$ & $1.68^{* *}(.32)$ & 1.38 \\
\hline Gender (female $=1$ ) & .96 & $1.51^{* *}(.11)$ & 1.14 \\
\hline Age & $.97^{* *}(.00)$ & $1.01^{* *}(.00)$ & 1.00 \\
\hline Length of stay (log) & $1.88^{* *}(.24)$ & $.62^{* *}(.05)$ & .91 \\
\hline Return wish & $1.79^{* *}(.18)$ & $2.49^{* *}(.21)$ & $2.56^{* *}(.27)$ \\
\hline \multicolumn{4}{|l|}{ Reason migration (other=ref) } \\
\hline War & $.66^{\circ}$ & 1.18 & 1.10 \\
\hline Fear of personal persecution & $.64^{\sim}$ & 1.17 & .95 \\
\hline Family reunification & .74 & 1.33 & $1.65^{\circ}$ \\
\hline $\mathrm{Chi}^{2}$ & $\mathrm{df}(15)=332.9$ & $\operatorname{df}(17)=476.7$ & $\mathrm{df}(17)=442.0$ \\
\hline Nagelkerke $R^{2}$ & .10 & .07 & .12 \\
\hline
\end{tabular}

Note: ${ }^{* *} p<.01,{ }^{*} p<.05, \sim p<.10$

Family reunification in order to distinguish from other info on the model (chi2 and r2)

Obvious differences are found in the performance of economic and sociocultural transnational activities among refugee groups. The likelihood of remitting is the largest for the Somali and Afghan group and the smallest for the Iranian group (Table 7). This is contrary to want we expected under the resource dependent transnationalism thesis. So, even though the socioeconomic position of the Somalis in the Netherlands is the lowest of all refugee groups under study, which implies that they have the least capaci- 
ties to perform transnational behaviour, they are the most frequent remitters. This finding is in line with former findings in Norway that, despite their low income, Somali refugees are the most regular remitters (Carling, 2008).

Also when individual capacities are included in the model these differences remain. Thus, the observed differences among the refugee groups are not solely due to the different modes of integration and individual capacities and desires. The analyses show that these factors alone cannot explain the observed differences among the refugee groups under study. This provides tentative support for the financial stress hypothesis $\left(\mathrm{H}_{4}\right)$ since also characteristics of the origin country and stay-behinds are of importance in understanding the performance of transnational activities. Since Iran has significantly higher GDP per capita and generally leave relatively wealthy families behind we argue that financial support is possibly less needed. This can partly explain the lower percentage of remittance sending within the Iranian group. On the contrary, Somalia being a country in poverty and conflict, the demand for financial support might be strong; which can explain why Somali refugees are the most frequent remitters.

Similarly, looking at the differences in maintaining contact with the family at home and visiting the origin country we observe, in congruence with our expectation, that the Iranian group is most likely and the Somali and Afghan group least likely to perform socio-cultural transnational activities. On the individual level this can partly be due to the feelings of perceived acceptance; Somalis feel most accepted and therefore perhaps have less desire to remain in contact with the origin country. However, these differences also remain when perceived acceptance is included in the model. This provides tentative support for the facilities hypothesis $\left(\mathrm{H}_{5}\right)$, since the observed differences cannot be explained by the individual host country situation. It thus seems that indeed the limited communication possibilities and the current safety situation in Somalia can provide an explanation for the low likelihood of the Somali group to perform socio-cultural transnational activities. Again, since Iran is holding the best (welfare) position and has by far the most telephone and internet users it seems plausible for them to perform the most socio-cultural transnational activities.

\section{$7 \quad$ Conclusion and discussion}

In this paper we aimed to explain the performance of transnational activities of the four largest refugee groups in the Netherlands in a comparative perspective. First, we found support for the resource dependent transna- 
tionalism thesis, since employment, education and health are important factors that affect the capacities of refugees to remit, to maintain contact with family in the country of origin and to visit the origin country. In other words, (economic) integration in the host country benefits the performance of transnational behaviour. Further, having the Dutch nationality is of great importance for performing socio-cultural transnational activities. This seems to indicate that for refugees the security, safety and protection provided by a Dutch passport enable them to maintain contact with and visit family in the origin country. Again, integration and transnationalism are compatible and even reinforcing.

In general we thus find that the mechanism of resource dependent transnationalism is confirmed for all refugee groups. However, looking at the separate refugee groups we conclude that there is more to it. Despite having a low level of economic integration in the host country, the Somali group is the most frequent remitter. Iranians, on the contrary, are better economically incorporated but the least frequent remitters. The simple general assumption that low-income migrants are not able to remit seems to be insufficient to explain the pattern of refugees' transnational behaviour. A possible explanation for this unexpected finding lies in the nature of the host country. The Netherlands is a social welfare state where everyone, also without employment, is provided with a basic income which lies almost at the level of the minimum wage. Thus, even refugees who do not hold a job do have the resources to remit.

Following from this paper we propose a second explanation for these seemingly contradictory findings: the origin country situation. The general welfare situation, according to the Human Development Index, in Somalia and Afghanistan is considerable worse compared to Iran. Therefore the potential need for financial support of the stay-behinds in Somalia is assumed to be larger. Moreover, considering the enormous relative wealth difference between Somalia and the Netherlands, each amount, even an amount of remittances that is considered to be small in the Netherlands, is of great value for stay-behinds in Somalia. Whereas the stay-behinds of Iranians, who more often are from middle class families, are less dependent on remittances from family abroad. In addition, due to limited internet and telephone facilities in Somalia, staying in contact with stay-behinds in the origin country is difficult. Last, conflict in the origin country can be a serious obstacle for visiting the home country. Again this applies mostly to Somalia, since this country is suffering from most conflict of the four countries under study. All together this paper provides tentative sup- 
port for the importance of the economic and social situation in the origin country for explaining refugees' transnational behaviour.

In this study we showed the importance of both the resources available to refugees in the host country and the potential need for resources in the origin country for explaining refugees' transnational behaviour; it is a twoway process. Unfortunately we were not able to test the impact of country characteristics directly. Future research could take up the challenge and include such macro characteristics of the home country and more specific information on the stay-behinds in the analysis in order to test their separate effects.

This paper has clearly shown that the relation between integration and transnationalism for refugees is complex and intertwined. On the one hand, integration benefits the performance of transnational behaviour. Thus, having a job or good education enables refugees to remit and stay in touch. On the other hand, we should not lose out of sight that demands from the origin country do also affect refugees' behaviour. To conclude, the pattern of the performance of transnational activities of refugees is strongly characterised by resource dependent transnationalism. In addition, this paper drew attention to the importance of the economic and social situation in the origin country in explaining transnationalism for refugee groups.

\section{Notes}

1. Statistics Netherlands distinguishes between western and non-western countries. Western countries are all European countries including Central and Eastern Europe (except Turkey), North American countries, some Asian countries (Japan and Indonesia), and the countries in Oceania (Australia and New Zealand). Turkey and all countries in Latin and South America, Africa and Asia are considered non-western.

2. Somalia has the lowest rank (158) on the Global Peace Index 2012 (a product of Institute for Economics and Peace). Closely followed by Afghanistan (157), Iraq (155) and again Iran holds the best position (128), also regarding conflict.

3. This also means that the non-response is about $50 \%$ per group. The largest share of non-response is due to refusal. Not having reached respondents at home after 6 approaches is another reason for non-response. Those addresses that for unknown reasons have not been approached by the interviewers are also included in the non-response.

4. Those refugees who have no family in the origin country are excluded $(n=203)$.

5. The category 'not possible to visit' was excluded from the analysis to explain visits to 
the origin country. Note that these respondents are included in the models to explain remittances and contact behaviour.

\section{References}

Al-Ali, N., Black, R., \& Koser, K. (2001a). The limits to 'transnationalism': Bosnian and Eritrean refugees in Europe as emerging transnational communities. Ethnic and Racial Studies, 24, 578-6oo.

Al-Ali, N., Black, R., \& Koser, K. (2001b). Refugees and transnationalism: the experience of Bosnians and Eritreans in Europe. Journal of Ethnic and Migration Studies, 27, 615-634.

Alba, R. \& Nee, V. (1997). Rethinking assimilation theory for a new era of immigration. International Migration Review, 31, 826-874.

Carling, J. (2008). The determinants of migrant remittances. Oxford Review of Economic Policy, 24, 581-598.

Carling, J., Erdal, M.B., \& Horst, C. (2012). How does conflict in migrants' country of origin affect remittance-sending? Financial priorities and transnational obligations among Somali and Pakistani in Norway. International Migration Review, 46, 283-309.

Carling, J., \& Hoelscher, K. (2013). The capacity and desire to remit: Comparing local and transnational influences. Journal of Ethnic and Migration Studies, DOI:10.1080/1369183X.2013.765657.

Clark, K., \& Drinkwater, S. (2007). An investigation of household remittances behaviour: Evidence from the United Kingdom. The Manchester School, 75, 717-741.

DeSipio, L. (2002). Sending money home.. for now: Remittances and immigrant adaptation in the United States. In: Garza, de la R.O., \& Lowell, B.L. Sending Money Home. Hispanic Remittances and Community Development. Maryland: Rowman and Littlefield Publishers.

Díaz-Briquets, S., \& Péréz-López, J. (1997). Refuge remittances: Conceptual issues and the Cuban and Nicaraguan experiences. International Migration Review, 31, 411-437.

Dourleijn, E. (2010). Survey Integratie Nieuwe Groepen 20og: verantwoording van de opzet van een survey onder Afghaanse, Iraanse, Iraakse, Somalische, (kort verblijvende) Poolse en Chinese Nederlanders en een autochtone Nederlandse vergelijkingsgroep. Den Haag: Sociaal en Cultureel Planbureau.

Dourleijn, E., \& Dagevos, J. (2011). Vluchtelingengroepen in Nederland: Over de integratie van Afghaanse, Iraanse, Iraakse en Somalische migranten. Den Haag: Sociaal en Cultureel Planbureau.

Erdal, M.B., \& Oeppen, C. (2013). Migrant balancing acts: Understanding the interactions between integration and transnationalism. Journal of Ethnic and Migration Studies, DOI:10.1080/ 1369183X.2013.765647.

Ghorashi, H. (2005). Agents of Change or Passive Victims: The Impact of Welfare States (the Case of the Netherlands) on Refugees. Journal of Refugee Studies, 18, 181-198.

Glick Schiller, N., Basch, L., \& Blanc-Szanton, C. (1992). Towards a Transnational Perspective on Migration. New York: New York Academy of Sciences.

Glick Schiller, N., \& Fouron, G. (1998). Transnational lives and national identities: The identity politics of Haitian immigrants. Comparative Urban and Community Research, 6, 130-161.

Hagen-Zanker, J., \& Siegel, M. (2007). The determinants of remittances: A review of the literature. Working paper, Maastricht, Maastricht Graduate School of Governance.

Hessels, T. (2000). Somaliers in Nederland. Een profiel. Den Haag: ministerie van Binnenlandse Zaken en Koninkrijksrelaties. 
Hessels, T. (2002). Iraniers in Nederland. Een profiel. Den Haag: ministerie van Binnenlandse Zaken en Koninkrijksrelaties.

Hessels, T., \& Wassie, F. (2003). Afghanen in Nederland. Een profiel. Den Haag: ministerie van Binnenlandse Zaken en Koninkrijksrelaties.

Horst, C. (2008). The transnational political engagements of refugees: Remittance sending practices amongst Somali in Norway. Conflict, Security \& Development, 8, 317-338.

Itzigsohn, J., \& Saucedo, S.G. (2002). Immigrant incorporation and sociocultural transnationalism. International Migration Review, 36, 766-798.

Johnson, P.J., \& Stoll, K. (2008). Remittance patterns of southern Sudanese refugee men: Enacting the global breadwinner role. Family Relations, 57, 431-443.

Levitt, P., \& Jaworsky, B.N. (2007). Transnational migration studies: Past developments and future trends. Annual Review Sociology, 33, 129-156.

Lindley, A. (2008). Conflict-induced migration and remittances: exploring conceptual frameworks. Oxford: Refugee Studies Centre.

Marcelli, E.A., \& Lowell, B.L. (2005). Transnational twist: Pecuniary remittances and the socioeconomic integration of authorized and unauthorized Mexican immigrants in Los Angeles County. International Migration Review, 39, 69-102.

Mascini, P., Fermin, A., \& Snick, H. (2012). Transnationalism of Burundian refugees in the Netherlands: The importance of migration motives. International Journal of Population Research, DOI:10.1155/2012/962327.

Mazzucato, V. (2008). The double engagement: Transnationalism and integration. Ghanaian migrants' lives between Ghana and the Netherlands. Journal of Ethnic and Migration Studies, 34, 199-216.

Menjívar, C., Davanzo, J., Greenwell, L., \& Valdez, B. (1998). Remittances behavior among Salvadoran and Filipino immigrants in Los Angeles. International Migration Review, 32, 97-126.

Muller, P. (2010). Scattered families. Transnational family life of Afghan refugees in the Netherlands in the light of the human rights-based protection of the family. $\mathrm{PhD}$ thesis: Utrecht University.

Nieuwhof, A., \& Mahamoud, A. (200o). Communicatie, sleutel en participatie. De Somalische gemeenschap in Nederland. Den Haag: ministerie van Binnenlandse Zaken en Koninkrijksrelaties.

Portes, A. (1999). Conclusions: Toward a New World - The Origins and Effects of Transnational Activities. Ethnic and Racial Studies, 22, 464-477.

Portes, A., Guarnizo, L.E., \& Landolt, P. (1999). The study of transnationalism: pitfalls and promise of an emergent research field. Ethnic and Racial Studies, 22, 217-237.

Portes, A., Haller, W., \& Guarnizo, L.E. (2002). Transnational entrepeneurs: An alternative form of immigrant economic adaptation. American Sociological Review, 67, 278-298.

Sana, M., \& Massey, D.S. (2005). Household Composition, Family Migration, and Community Context: Migrant Remittances in Four Countries. Social Science Quarterly, 86, 509-528.

Snel, E., Engbersen, G., \& Leerkes, A. (2006). Transnational involvement and social integration. Global Networks, 6, 285-308. 
Vertovec, S. (2001). Transnationalism and Identity. Journal of Ethnic and Migration Studies, 27, $573-582$.

Wong, L.L. (2007). Transnationalism, active citizenship, and belonging in Canada. International Journal, 63, 79-99.

\section{About the authors}

Linda Bakker is a PhD candidate at the Erasmus University Rotterdam in the Netherlands. Her dissertation is about the integration of refugee groups in the Netherlands. Within this topic she studies the impact of asylum policies, (mental) health, legal status, over-education and transnationalism. Her work is mostly quantitative and based on advanced methods. Linda is the corresponding author for this manuscript. E-mail: l.bakker@fsw.eur.nl

Prof. dr. Godfried Engbersen is professor of Sociology at the Erasmus University of Rotterdam, the Netherlands, and an elected member of the Royal Netherlands Academy of Sciences (KNAW). He is an expert on social inequality, immigration and urban social problems. Currently he is working on the relationship between restrictive migration regimes and crime, local and transnational citizenship, and liquid migration from Central and Eastern Europe. E-mail: engbersen@fsw.eur.nl

Dr. Jaco Dagevos is head of the research group Education, Minorities and Methodology at the Netherlands Institute for Social Research in The Hague. He is an expert in the field of migration and integration of minorities in the Netherlands, with a focus on labour market participation and discrimination. E-mail: j.dagevos@scp.nl 